\title{
Is there an Economic Case for Energy-Efficient Dwellings in the UK Private Rental Market?
}

\author{
BY \\ FRANZ FUERST* \\ UNIVERSITY OF CAMBRIDGE \\ MiCHEL HADDAD \\ UNIVERSITY OF CAMBRIDGE \\ HASSAN ADAN
}

CENTRE FOR ECONOMIC AND BUSINESS RESEARCH, LONDON, UK

* Corresponding author: University of Cambridge, Department of Land Economy, Cambridge CB3 9EP, UK, e-mail: ff274@cam.ac.uk.

\section{Acknowledgment:}

This research was supported by Grant H2020-EE-2014-2015 of the European Commission and is part of the RentalCal project (www.rentalcal.eu) and by the Department of Business Energy and Climate Change of the UK. The authors are grateful for comments received from Chris Nicholls, Sarah Sayce, Fiona Haggett, Bowie Penney and three anonymous referees. All errors remain our own. 


\title{
Is there an Economic Case for Energy-efficient Dwellings in England's Private Rental Market?
}

\begin{abstract}
The rented sector of the housing market is a key concern for policies trying to improve dwelling-level energy efficiency levels. Currently, stepping up energy efficiency levels in the residential sector is hindered by a number of uncertainties. For rental properties, this is complicated by the split incentive problem (i.e. landlords do not benefit directly from the savings arising from these investments). Instead, the benefits are enjoyed by the tenants of these upgraded properties via lower energy bills and/or enhanced thermal comfort. Hence, the only way to recoup the investments is typically for landlords to obtain higher rents. This study confirms that energy efficiency features, as measured by the Energy Performance Certificate rating, are positively associated with a small but significant influence on transaction prices and quoted rental prices. Conversely, there appears to be a price discount for dwellings in the lowest energy performance category. A model of time-on-market yields inconclusive results but there is some, albeit weak, evidence of a negative relationship between time-on-market and energy efficiency ratings as more energy efficient dwellings tend to lease up more quickly.
\end{abstract}

Keywords: Energy efficiency; Green property; Hedonic model; Private rental market; Split incentives; Sustainability

\section{Introduction}

The present study focusses on a crucial sector of the housing market, the Private Rented Sector (PRS), which has experienced high growth rates in recent years and now provides housing to some five million households in the UK (Paragon, 2015). Apart from its size and importance, the PRS also presents an economic dilemma not typically observed in the owner-occupied segment. This dilemma which is effectively a barrier to achieving higher energy efficiency is known as the split incentive problem and arises because capital investments in energy efficiency are made by one party, the landlord, but the benefits are reaped by another, the tenant, as the latter enjoy lower utility bills and enhanced thermal comfort. Hence, the only 
economic channel for recouping the initial capital outlay is the landlord's ability to charge a higher rent. Whether higher rents are indeed achievable for properties with higher energy efficiency is therefore a crucial question which landlords and property investors need to consider before committing to an investment (Adan and Fuerst, 2015).

Closely related to the question of an energy efficiency rent premium is the question of transaction prices. Price signals are a key feature of markets. When information about important characteristics of a good is unavailable or expensive to obtain, price signals may be used to indicate quality and attractiveness. Real estate buyers need to determine and screen out low-quality assets from high-quality ones despite not being able to directly and fully observe the quality characteristics. With regard to the energy efficiency performance of a building, potential sellers are often unable to directly verify intrinsic green attributes of a property and must rely on incoming information from the marketplace in the form of eco-labels.

To improve the information available to those in the PRS in EU countries, an Energy Performance Certificate (EPC) must be provided by the landlord to the tenant before a property can be let out or sold. Overall, the current situation is marked by uncertainties that impede further progress towards greening of the UK housing stock. For landlords, uncertainty persists over key parameters, such as the payback period and market acceptance of rent increases. For tenants, energy efficiency ratings and/or even energy bills from previous tenants may only have limited predictive power for their own energy consumption.

The present study first examines a sample of PRS properties in England with a hedonic regression model, dividing a property's price into different components related to its corresponding characteristics, in order to establish if home energy efficiency can lead to increased property sales prices. The results indicate that high EPC ratings in dwellings are generally associated with a price premium and vice versa for low ratings. 
In the second part of this paper, rental rates and time-on-market are analysed using the same analytical framework. A rental premium is found for energy efficient properties, even when controlling for a number of rental determinants. These findings suggest that capitalisation of green features into rental and sale prices are likely to accelerate the adoption of energy efficient buildings.

The contribution of the present paper is twofold. It differs from previous studies by being, to the best knowledge of the authors, the first study to present a rigorous economic analysis of the value of energy efficiency in the English private rented sector by combining a rich database previously inaccessible to researchers evidence with public data on amenities and socioeconomic population characteristics. The second contribution is more general in that it seeks to explore if a largely unregulated rental market such as the UK yields price and rent capitalisation from EPCs that are comparable to the more regulated markets in mainland Europe. It is not straightforward to formulate an expectation prior to empirical testing. On the one hand, more regulated markets tend to provide more clarity to landlords and tenants on legally allowable rent increases following a green retrofit which may help gains in energy efficiency to manifest themselves in rents and prices more easily. On the other hand, where these more regulated markets also grant considerable subsidies and tax deducations for making homes more energy efficient, landlords may not seek to recoup their expenses via the rent channel to the same extent as their peers in non-regulated markets. Hence, the level of capitalisation would be expected to be lower in a relatively unregulated market. Following this introduction, the paper is divided into five sections. Section two discusses relevant previous studies. Section three details the hedonic pricing model. Section four explores the datasets and descriptive statistics. Section five provides a discussion on the regression outputs. Section six concludes and suggests extensions for future research.

\section{State of research}


Studies of barriers to achieving greater energy efficiency in the existing building stock typically focus on either technical or non-technical barriers (Femenías et al., 2018). A comprehensive discussion of technical barriers can be found in O'Malley and Sorrell (2003). Non-technical obstacles can be divided into four categories: limitations on decision-making, rational behaviour, organisational failures, and market failures - e.g. imperfect information and split incentives (Sorrell, 2003).

The present study is closely related to the non-technical obstacles branch of literature, by empirically exploring market failures in the PRS in England through property prices. An important problem explored in this paper is related to split incentives as a consequence of the information asymmetry problem. Information asymmetries between homeowners and tenants negatively impact the adoption of building energy efficiency measures, consisting of an effective barrier to increase green property investments (Jaffe and Stavins, 1994; Femenías et al., 2018).

Very few studies have attempted to quantify the price effect of energy efficiency levels in the residential market, let alone the PRS. Below is a short review of the main existing empirical evidence.

\subsection{Energy efficiency and sales prices}

Despite the fact that there is a wide variability on the scale of price effects on energy efficiency, the empirical results provided by the present paper are broadly consistent with most of the studies in the literature, in which positive relationships between property prices and energy efficiency are reported. However, few studies find divergent results, concluding that either energy performance is not necessarily rewarded (Cerin et al., 2014) or even energy efficiency being negativey related to property price (Yoshida and Sugiura, 2010). 
Berry et al. (2008) conducted one of the first studies on the effect of mandatory green certification on residential house prices. The study reports a significant relationship between the energy efficiency rating of a dwelling and its sale price in Australia between 2005 and 2006, with premiums of $1.23 \%$ found in 2005 and $1.91 \%$ in 2006 , in response to a 0.5 score increase on the 0-10 energy rating scale.

In the European Union, Brounen and Kok (2011) examined the impact of energy labels on house prices in the Netherlands. Residential properties with an above-average green label rated A, B and C command premiums of $10 \%, 5.5 \%$ and $2.2 \%$ respectively. In a parallel study in Ireland, Hyland et al. (2013) show that there is an 9.3\% price premium for A-rated dwellings, 5.5\% premium for $\mathrm{B}$ ratings, and a significant $-10.6 \%$ discount for $\mathrm{F}$ and $\mathrm{G}$ ratings. A small but positive relationship between energy performance and sale prices is also found for the housing market in Northern Ireland (Davis et al., 2015).

Studies conducted in the UK draw a similar conclusion. Fuerst et al. (2015), using 325,950 dwellings sold at least twice from 1995 to 2011, report significant positive premiums for dwellings rated $\mathrm{A} / \mathrm{B}(5 \%)$ or $\mathrm{C}(1.8 \%)$. For dwellings rated $\mathrm{E}(-0.7 \%)$ and $\mathrm{F}(-0.9 \%)$, significant discounts are found. Recent studies in Nordic countries - Denmark (Jensen et al., 2016) and Finland (Fuerst et al., 2016), confirm a significant role of energy efficiency ratings for sale prices.

The consensus of a green premium in the housing market is not unanimous among all studies. An important theoretical economic argument underpinning the lack of a premium would be that landlords are already charging the maximum obtainable rent. This argument has its antecedents in Ricaridian rent theory and has been reformulated by Samuelson (1959). When housing markets are inelastic, this entails that housing supply is fixed. In this situation, 
landlords would charge the maximum rent they can obtain from tenants based on the latter's wages, which reflect the marginal product of their labour. Therefore, any improvements in energy efficiency may remain unrewarded if tenants already pay the maximum share of their incomes. For example, the two empirical studies below find a negligible impact on prices.

Using Swedish housing transactions between 2009 and 2010, Cerin et al. (2014) show that energy performance is not rewarded across all property-price classes and ages of residential properties and conclude that there is little evidence of price penalties for the least energy efficient properties, although, within the most energy efficient houses, a significant association between energy performance and house prices is reported. Similarly, Yoshida and Sugiura (2010) show a significant price discount of 5.5\% and a lower depreciation rate for newly constructed green condominiums in Tokyo. Interestingly, this suggests that properties with high energy efficiency ratings are likely to command lower market prices.

Appendix A provides an overview of empirical studies examining the impact of energy efficiency on house prices, in which there is a slight trend towards smaller green premiums in recent studies.

\subsection{Energy efficiency and rents}

Empirical studies examining the capitalisation of energy efficiency in the PRS are rare. The apparent gap in the literature is not surprising. Quality concerns and suitability of available data are often cited limitations and there is no clear consensus on the scale of the price effect of energy efficiency. Case studies from Sweden, Germany, and Ireland all report a positive relationship between energy efficiency and residential rents.

Zalejska-Jonsson (2014) shows a premium of 5\% of total rent in green buildings in Sweden. 
Similarly, Hyland et al. (2013) report that A-rated properties have a green sale price premium of $11 \%$ and a green rent premium of $1.9 \%$ in the Irish residential market. Interestingly, not only does this study suggest a positive relationship between energy efficiency and rental and sale prices, but it also suggests that buyers exhibit a stronger willingness to pay more for energy efficiency than tenants.

Cajias and Piazolo (2013) find a rent premium of 1.7\% in the German market. In related research, Kholodilin et al. (2017) found that energy efficiency are generally capitalised into rental prices in Berlin. Earlier, Rehdanz (2007) arrived at similar conclusions exploring the German housing market.

\section{Research design}

The hedonic pricing model is the standard methodology for examining value determinants in housing. In the present study, this method is used to primarily isolate the effect of EPC rating on price, taking the following fully linear form (Rosen, 1974):

$$
\boldsymbol{P}_{i t}=\beta_{0 t}+\sum_{k=1}^{K} \beta_{k t} \boldsymbol{X}_{i k t}+e_{i t}
$$

where $\boldsymbol{P}_{i t}$ is the transaction price of property $i$, measured as the natural logarithm of the price in GBP per square metre $\left(\mathrm{m}^{2}\right)$ at time $t$, in which $t=0 \ldots T$, and $\boldsymbol{X}_{i k t}$ is a vector of $K$ explanatory locational and physical characteristics, including categorical variables related to energy labelling and property characteristics. Note that the present analysis uses the sale price per square metre rather than the total recorded price. This reduces the predictive power of the model but provides a more robust measure of prices as it eliminates the size effect contained in the recorded transaction price. The term $\beta_{0 t}$ refers to the intercept, $\beta_{k t}$ is a vector of characteristics parameters to be estimated, and $e_{i t}$ is a random error term (white noise) with mean zero, capturing additional factors impacting house prices. The hedonic weights assigned 
to each variable are equivalent to their overall contribution to price. The estimation of rents adopts the following functional form:

$$
\begin{aligned}
\log R_{i t}=\beta_{0}+ & \beta_{1} \sum_{k=1}^{K} \text { Physical characteristics }_{i t} \\
& +\beta_{2} \sum_{k=1}^{K} \text { Locational characteristics }_{i t} \\
& +\beta_{3} \sum_{k=1}^{K} \text { Neighborhood profile }_{i t}+\beta_{4} \sum_{k=1}^{K} \text { EPC rating }_{i t}+\epsilon_{i t}
\end{aligned}
$$

The dependent variable $\log R_{i t}$ is the natural logarithm of the asking rent per $\mathrm{m}^{2}$ in GBP, indexed by property $i$ and time $t$. The logarithmic-linear model specification is the preferred functional form due to the fact that it mitigates the effect of extreme values and it facilitates the interpretation of the coefficient as average percentage premiums/discounts.

Previous emprical studies on rental determination provide no conclusive list of variables to be included in the model. In order to isolate the effect of the environmental certificate on rent, the focus is on housing units' physical characteristics as well as neighbourhood characteristics. The term $\beta_{k t}$ is a vector of parameters that captures the marginal effect each attribute $\left(X_{i k t}\right)$ of the rental unit has on the rental rate:

$$
\partial X_{i k t} / \partial R_{i t}=\beta_{k t}
$$

$\epsilon_{i t}$ is a random composite error term, assumed to be independent across observations and normally distributed, with mean zero and constant variance $\sigma^{2}$. The independent variable of interest is the vector of energy effiency ratings, which controls for the property energy performance rating. Hedonic estimates can be biased due to the omitted-variable bias (OVB) problem. While every effort has been made to include all relevant value drivers in the current analysis, further details on limitations of hedonic pricing models can be found in Balk et al. (2013). 


\section{Data and descriptive statistics}

The hedonic analysis outlined above requires a large sample of property transaction prices and characteristics. For the purpose of the present study, data from several sources were merged.

\subsection{Dataset building}

In the first step, data on market prices were obtained from the UK's Land Registry, comprising residential transaction prices from 1995 to 2013. In the second step, through address matching, this data was cross-referenced with the HomeCo Internet Property Ltd rental data to obtain information on property size, dwelling type, age, and energy performance.

The sample was further enhanced by adding socio-economic data from the Office for National Statistics and indicators provided by the UK Census. Particularly the English Index of Multiple Deprivation (IMD), which contains an aggregation of the following seven neighbourhood profile domains: income; employment; education, skills and training; health and disability; crime; barriers to housing and services; and living environment. All reported to be important locational control variables in previous studies. Our model specifications included either the combined IMD score or its constituent elements but it was found that this choice does not significantly alter the results with regard to the variables of interest.

To ensure a representative sample, observations across hundreds of different neighbourhoods in England were obtained via a stratified random draw. The sample covers approximately 4,600 rental observations, which includes information on sale prices of virtually all of these properties. It is worth noting that the analysis was performed on a smaller number of observations (4,132 and 4,076 observations for sale prices and rental values respectively) due to missing values in their respective explanatory variables.

Fig. 1 compares the sample distribution with the population distribution of all EPCs reported by the Department for Communities and Local Government and the English Housing Survey. Despite minor differences, the data distributions can be considered sufficiently comparable. 
Additionally, the hedonic regression model should control for smaller variations between the sample and the underlying population.

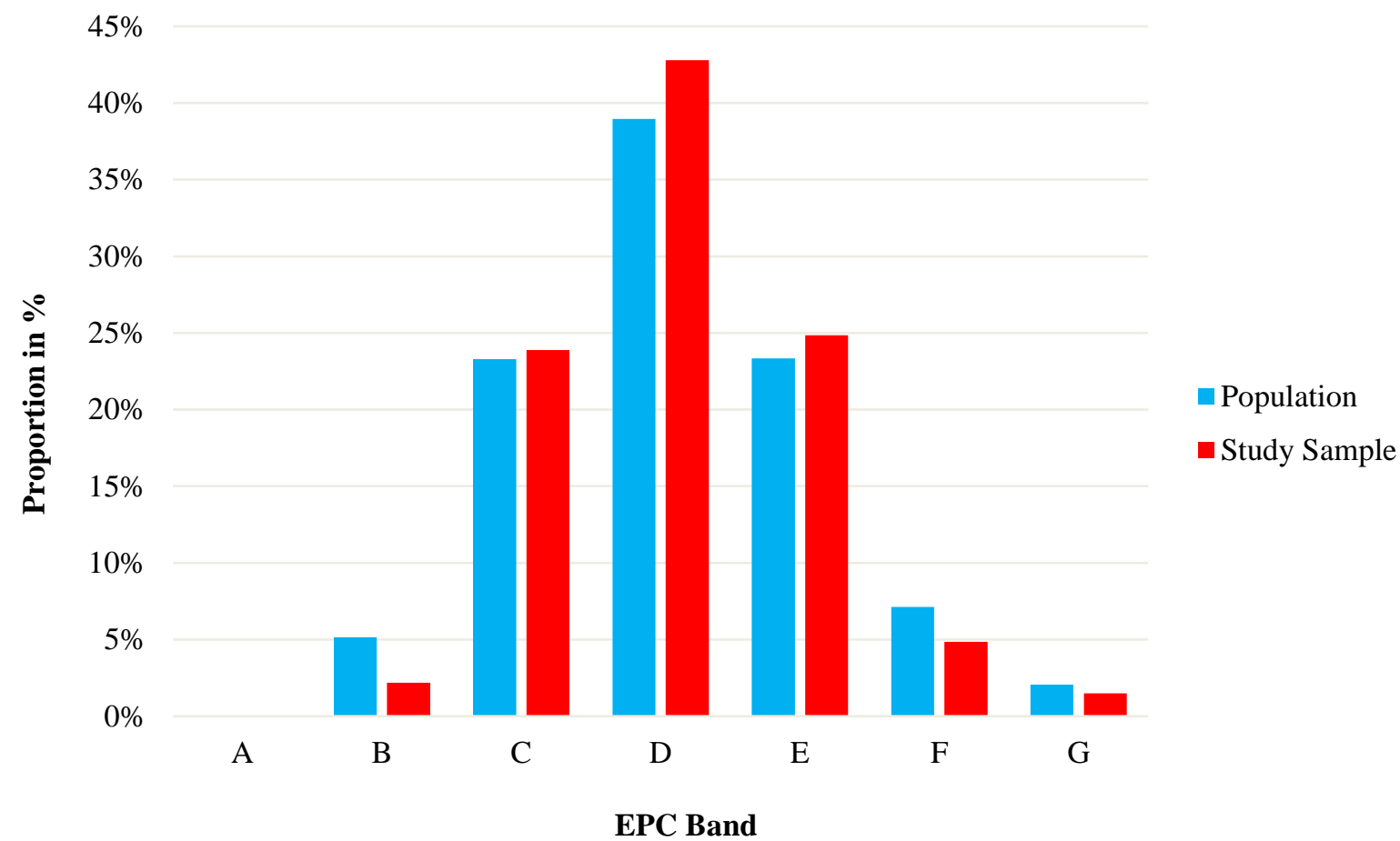

Fig. 1. Distribution of EPC bands for study sample (red) and external reference, DCLG (blue). Data sources: Landmark and DCLG.

A further concern is that important price determinants may be highly correlated with EPCs.

Fig. 2 confirms that the distribution of EPC bands varies considerably depending on the year of construction. Hence, it was necessary to include age of construction (vintage bands) in our model to disentangle these two effects. However, there may be other confounding effects that remain uncontrolled for even when building age is included in the model. For example, it is to be suspected that $\mathrm{F}$ and $\mathrm{G}$ rated properties could generally be in worse condition and have lower aesthetic appeal, inflating the price discount to buildings with low EPC ratings. Since there is no information on the condition of a property in the present study, it cannot be ruled out that these price drivers enter the calculated EPC price effects.

Similarly, it is possible that $\mathrm{F}$ and $\mathrm{G}$ rated properties are perceived to entail higher costs in the longer run, not only due to their substandard energy efficiency levels and higher energy bills 
but also in terms of general maintenance work. The equilibrium sales price would then adjust downwards to reflect the present value of these higher deferred costs.

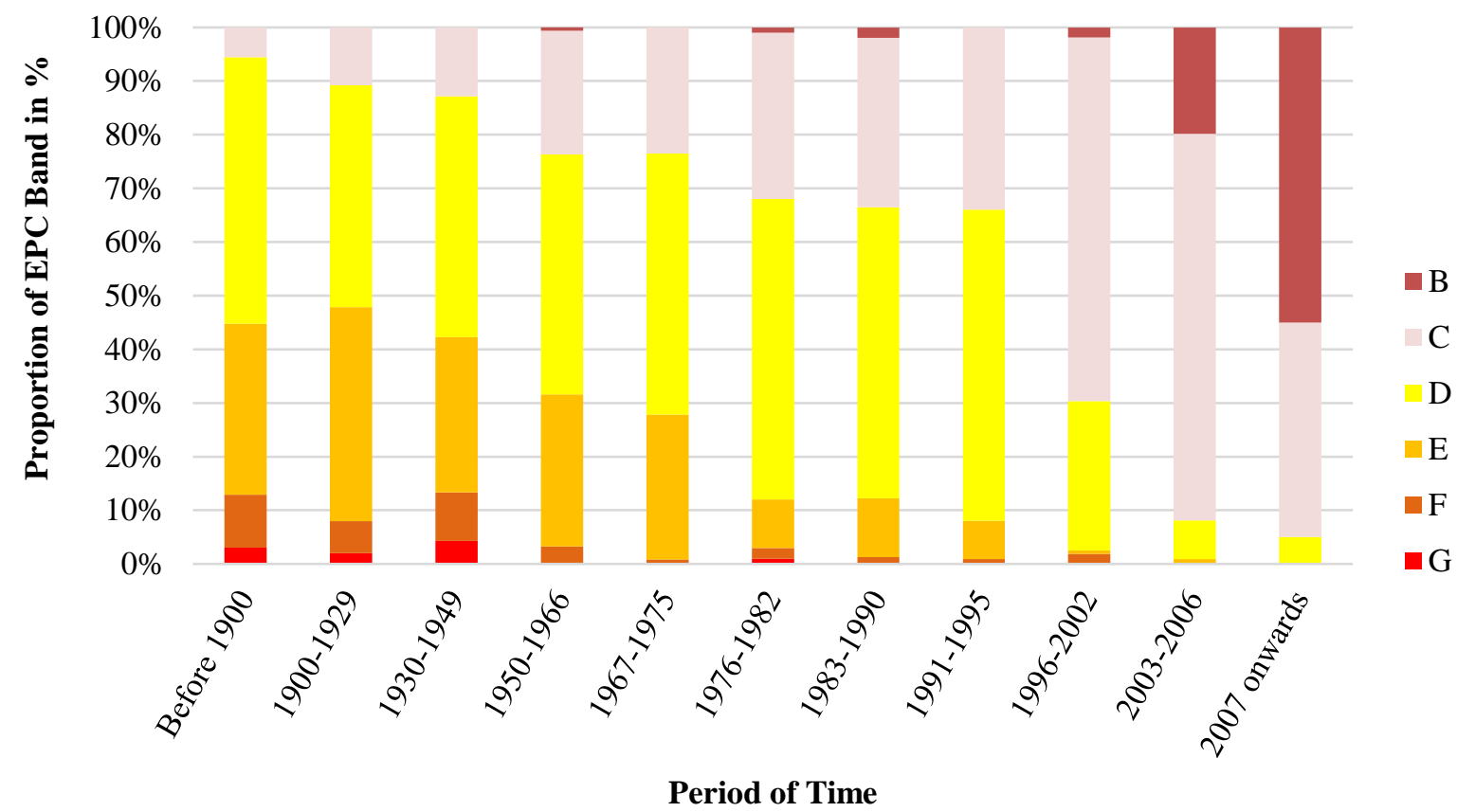

Fig. 2. Sample distribution by EPC band and vintage period. Data source: Landmark.

Information on rents and dwelling characteristics was also obtained from HomeCo. Efforts were made to ensure that each dwelling included in the sample had both an on-market and an off-market date. According to the data providers, this increased the likelihood of the asking rents in the sample matching the transacted rents.

This sample contains rental prices of 5,300 properties advertised for rent from 2011 to 2015 , along with corresponding information on property location, type, size, number of bedrooms, and vintage class. Socio-economic information from the census and the IMD were added, along with information on energy performance ratings obtained from the EPC register.

\subsection{Regression diagnostic and robustness checks}

A series of diagnostic and robustness checks were undertaken. As some flats and terrace houses are held on a leasehold basis, tenure was added as an additional control variable in the regression. Moreover, only properties which changed hands more than once were included in the sample to minimise measurement error and missing information. 
The Variance Inflation Factor (VIF) was also applied to test for multicollinearity. Overall, the estimation of the EPC price effects appears to be robust to these variations and tests, but it is important to bear in mind that the magnitude of these effects may still be distorted by correlated factors that were not included in the model.

\subsection{Key features of the dataset}

The descriptive statistics in Appendix B show interesting points. Average prices in the PRS in England seem to be lower than the overall housing market, which is consistent with evidence published by the Bank of England (Bracke et al., 2015). Also, in line with statistics from the English Housing Survey, the transacted buy-to-let properties are relatively smaller in size.

Almost half of the properties were constructed before 1950, with less than $6 \%$ built in the last decade. Terraced properties and flats account for approximately $54 \%$ and $10 \%$ of the sample, respectively. Most properties are also held in freehold. In contrast to leasehold, freehold tenure refers to a case in which the ownership of a building or plot of land is outright for an unlimited period of time. Overall, the properties appear to be spread evenly across the different deprivation levels.

Moreover, approximately two-thirds of the dwellings have EPCs rating below $\mathrm{C}$, with none being rated A and only $2 \%$ being rated B. Similarly, only $1.5 \%$ are in the G category. As low numbers in these categories may produce unreliable results, a combined $\mathrm{B} / \mathrm{C}$ category and a combined F/G category are formed. In line with previous studies, EPC ratings exhibit a strong correlation with building age.

The average monthly rental rates in England exhibit marked persistent differences as shown in Fig. 3, with listed rental prices in the South being priced significantly higher in comparison with the North. 


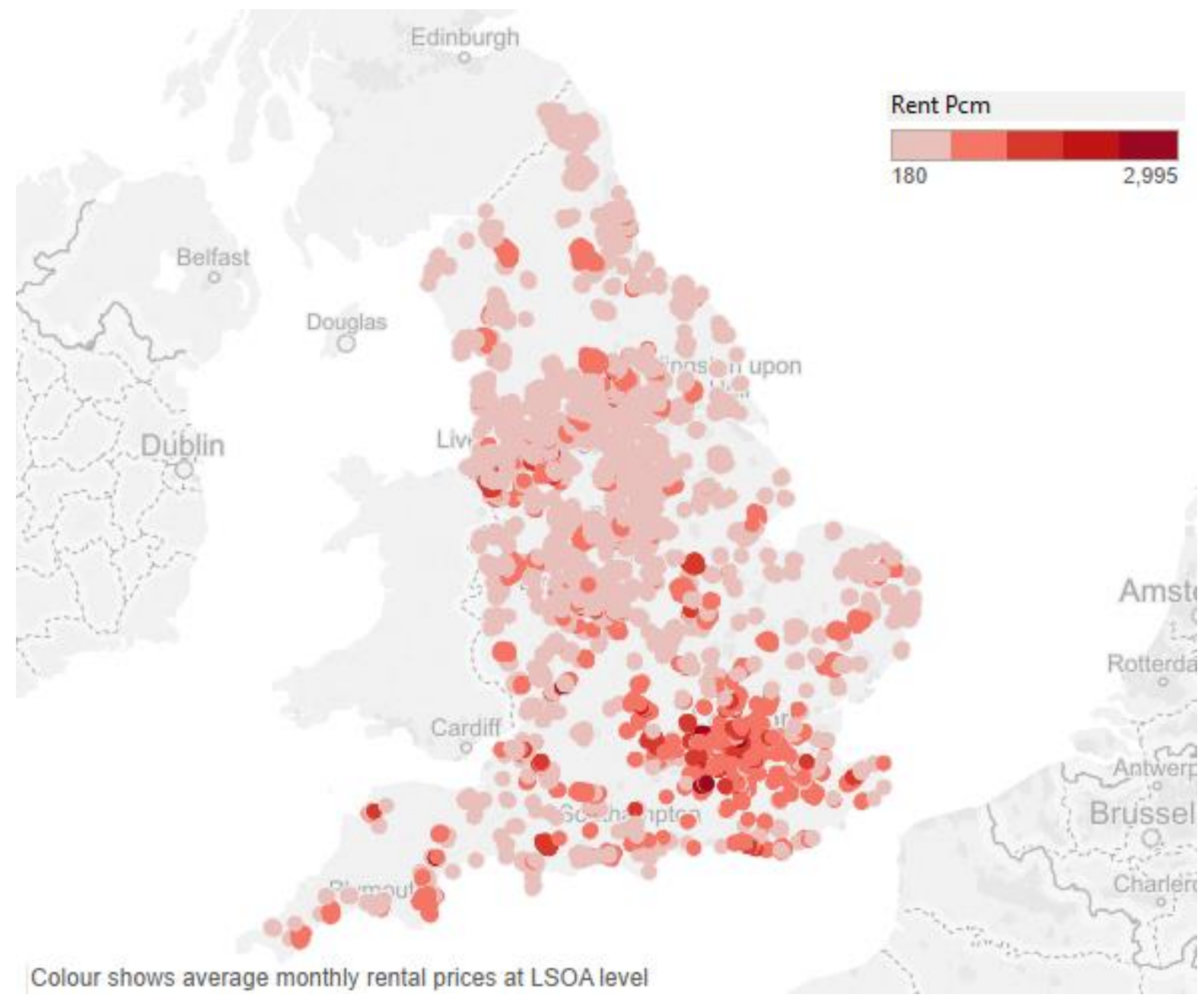

Fig. 3. Average monthly rental prices. Each dot represents an LSOA in England with lighter colours indicating lower rents and vice-versa.

In terms of marketing periods, Fig. 4 illustrates that, on average, they are higher in the North and relatively low in the Southeast and London. These differences in rental rates and marketing periods between the North and South of England is historically linked to differences in economic activity. These descriptive statistics are consistent with a priori expectations derived from market statistics. 


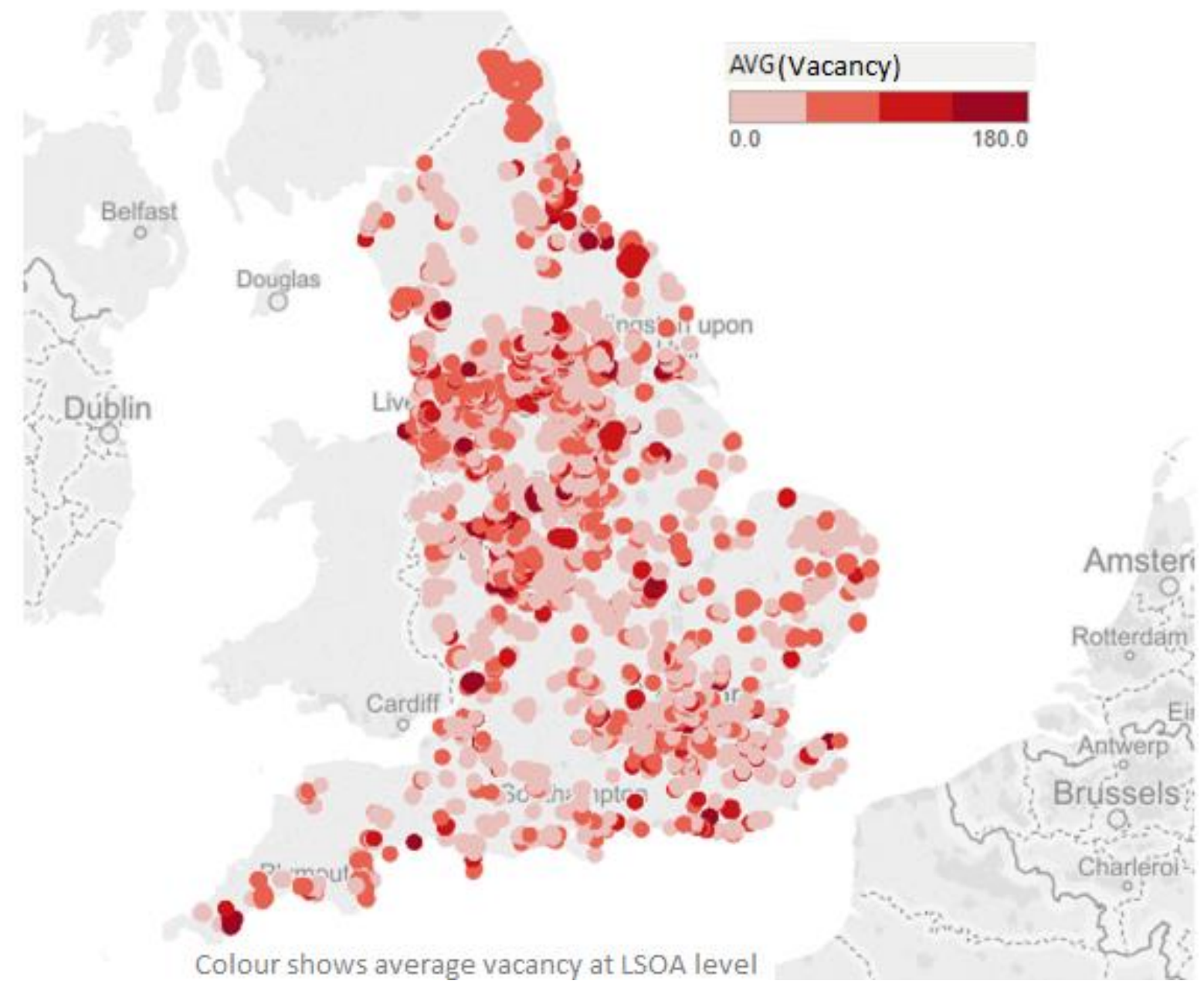

Fig. 4. Average time-on-market (difference between listing date and off-market date) at the LSOA level in England. Each dot represents an LSOA in England with lighter colours indicating shorter time on market and vice-versa.

Appendices D and E provide descriptive statistics of the categorical variables. The sample largely consists of flats and terraced houses and over $60 \%$ of the properties contain two bedrooms. The majority of the properties in the sample (86\%) are located in urban settlements. This is consistent with the spread of private rented properties in England.

In terms of socio-economic area characteristics, properties are spread evenly across the different levels of deprivation. The geographic spread of the observations in the sample is also statistically desirable, in which approximately $21 \%$ of the properties are located in the Northwest, 20\% in Yorkshire, 14\% in West Midlands, and $8 \%$ in the Greater London.

In line with the national average, $34 \%$ of the properties in the sample are in the D-rated category. There is, however, a clear shortage of A-rated properties (only 1 observation) and G- 
rated properties (less than $1 \%$ of the sample). In this study, for practical reasons, the sole Arated property in the sample is excluded and $\mathrm{F}$ and $\mathrm{G}$ rated properties are clustered together.

\section{Results and discussion}

The estimation results for the hedonic regression on log sale prices are shown in Table 1. The model fit as indicated by the R-squared captures between $43 \%$ and $44 \%$ of the variation in sale prices. This is in line with expectations since price per square metre rather than total price paid is used as the dependent variable.

Turning to the variable of interest, there is broadly a statistically significant relationship between the energy performance rating and the sale price of a dwelling. Relative to band $\mathrm{D}$, which is the most frequently reported EPC band and is thus used as the baseline category, the pattern of price effects reveals a significant and positive effect of approximately $6 \%$ for $\mathrm{B} / \mathrm{C}$ rated dwellings. For properties in the F/G category, depending on the specification, there is a statistically significant discount of $10-11 \%$ compared to D-rated properties. No significant relationship is found for E-rated properties. Model 2 is an alternative estimation using robust regression to account for influential observations that may exert leverage on sensitive coefficient estimates.

When the price per square metre is regressed against energy efficiency score and a vector of control variables (Model 3), a one percent increase in the 0-100 energy efficiency score produces an approximately $0.12 \%$ increase in the predicted dwelling price.

\section{Table 1}

Energy rating and sale price: hedonic estimations.

\begin{tabular}{lccc}
\hline Dependent variable: $\log$ sale price per $\mathrm{m}^{2}$ & $\begin{array}{c}\text { Model 1 } \\
\text { OLS (bands) }\end{array}$ & $\begin{array}{c}\text { Model 2 } \\
\text { Robust } \\
\text { regression }\end{array}$ & $\begin{array}{c}\text { Model 3 } \\
\text { OLS } \\
\text { (continuous) }\end{array}$ \\
\hline Log EPC & & & $\mathbf{0 . 1 1 9 * * * *}$ \\
EPC band = D vs.: & Reference & Reference & \\
EPC band B/C & $\mathbf{0 . 0 6 1 * * *}$ & $\mathbf{0 . 0 6 3}^{* * *}$ & \\
EPC band E & $\mathbf{0 . 0 0 4}$ & $\mathbf{0 . 0 0 1}$ &
\end{tabular}


EPC band F/G

Number of bedrooms

Log floor area in $\mathrm{m}^{2}$

Tenure freehold $=$ yes

Rural area $=$ yes

Purchased brand new

Log multiple IMD score

Constant

Vintage era fixed effects

Property type fixed effects

Quarterly fixed effects

Regional fixed effects

$R$-squared (model fit)

Sample Size

The asterisks show shown in Appendix C.

Next, rental rates are analysed to ascertain if the pricing relationships found in sales transactions also hold for the private rental market. The estimates in Table $\mathbf{2}$ provide a detailed description of rental prices as a function of their determinants. Each model explains a relatively large proportion of the variation in rent price. Depending on the specification, the number of bedrooms coefficient suggests that one additional bedroom increases the monthly rental price by approximately $10-11 \%$. The negative but significant relationship between rental price and floor area reflects that the rental price per $\mathrm{m}^{2}$ for the larger properties is likely to be relatively slightly lower than that of much smaller properties. Furthermore, there is a significant rental price premium of 5-7\% associated with rental units located in urban areas.

Turning to the price effects of EPC ratings, B-rated units are found to command a green rent premium of approximately $4 \%$ compared to the reference EPC band D. In addition, rental units with EPC band $\mathrm{C}$ show a similar rent premium, between $3 \%$ and $5 \%$ of rent. Conversely, F/Grated units present a rent discount of approximately 5\% in the robust estimation but this coefficient is not significant in the baseline OLS estimation. 
Given the large degree of heterogeneity in the rental stock, a closer investigation by property type seems warranted. Allen et al. (1995) argue that hedonic price functions may not be identical across property types since the structural parameters determining rent levels of flats (apartments) are likely to be different for other property types. Drawing on this insight, interaction terms involving property types and the natural logarithm of EPC rating were added to the regression in order to investigate this assumption. In Model 3, semi-detached, terraced house, and flats have a positive statistically significant relationship with log EPC in comparison with the reference category (i.e. detached vs. $\log$ EPC).

Moreover, as detailed in Appendix F, neighbourhood factors our found to be relevant determinants of rent levels, consistent with previous studies (Kain and Quigley, 1970; DiPasquale and Wheaton, 1992; Potepan, 1996).

Table 2

Energy rating and rental price: hedonic estimations.

$\begin{array}{cccc}\text { Dependent variable: } \log \text { of monthly rent per } \mathrm{m}^{2} & \text { Model 1 } & \text { Model 2 } & \text { Model 3 } \\ & \text { OLS } & \begin{array}{c}\text { Robust } \\ \text { regression }\end{array} & \begin{array}{c}\text { OLS with } \\ \text { interaction } \\ \text { terms }\end{array}\end{array}$

\begin{tabular}{lccc}
\hline Log EPC & & & $\mathbf{- 0 . 1 5 9}$ \\
EPC band = D vs.: & Reference & Reference & \\
EPC band B & $\mathbf{0 . 0 3 8}$ & $\mathbf{0 . 0 2 6}$ & \\
EPC band C & $\mathbf{0 . 0 4 9}$ * $* *^{*}$ & $\mathbf{0 . 0 3 0} * * *$ & \\
EPC band E & $\mathbf{- 0 . 0 0 1}$ & $\mathbf{0 . 0 0 1}$ & \\
EPC band F/G & $\mathbf{- 0 . 0 3 5}$ & $\mathbf{- 0 . 0 4 9} * *$ & \\
Interaction Terms (Property Type vs. Log EPC) & & & \\
Detached vs. Log EPC & & & Reference \\
Semi-detached vs. Log EPC & & & $0.237^{* *}$ \\
Terraced House vs. Log EPC & & & $0.239^{* *}$ \\
Flat vs. Log EPC & & & $0.247^{* *}$ \\
Number of bedrooms & $0.112^{* * *}$ & $0.096^{* * *}$ & $0.113^{* * *}$ \\
Log floor area in m ${ }^{2}$ & $-0.705^{* * *}$ & $-0.745^{* * *}$ & $-0.703^{* * *}$ \\
Tenure freehold = yes & 0.023 & 0.016 & 0.014 \\
City or Urban area = yes & $0.068^{* * *}$ & $0.051^{* * *}$ & $0.061^{* * *}$ \\
Log multiple IMD score & Components & $0.022^{* * *}$ & $0.021^{* * *}$ \\
Constant & $4.115^{* * *}$ & $4.828^{* * *}$ & $5.247^{* * *}$
\end{tabular}




\begin{tabular}{lccc} 
Quarterly fixed effects & Yes & Yes & Yes \\
Regional fixed effects & Yes & Yes & Yes \\
\hline$R$-squared (model fit) & 0.63 & 0.52 & 0.62 \\
Sample Size & 4,076 & 4,076 & 4,076 \\
\hline Asterisks indicte significance levels: ${ }^{*} \mathrm{p}=0,05, *^{*} \mathrm{p}=0.01$ and ${ }^{* * *} \mathrm{p}=0.001$ & Robust standard errors are
\end{tabular}

Asterisks indicate significance levels: $* \mathrm{p}=0.05,{ }^{* *} \mathrm{p}=0.01$ and $* * * \mathrm{p}=0.001$. Robust standard errors are used. Complete results are shown in the Appendix F.

Finally, Table 3 reports the results for time-on-market, defined as the number of days between making a letting advert available on-line and removing it, against the full set of control variables. It is, however, apparent that the explanatory power of the models is generally low and that most of the coefficients are not statistically significant. This is not surprising as several important determinants of the time on market such as individual over or underpricing and the number of competing rental units listed for rent at any given time are not represented in the estimation equation.

Table 3

Energy rating and time-on-market: hedonic estimations.

\begin{tabular}{|c|c|c|c|}
\hline Dependent variable: $\log$ of time-on-market in days & $\begin{array}{c}\text { Model } 1 \\
\text { OLS }\end{array}$ & $\begin{array}{c}\text { Model } 2 \\
\text { Robust } \\
\text { regression }\end{array}$ & $\begin{array}{c}\text { Model } 3 \\
\text { OLS with } \\
\text { interaction } \\
\text { terms }\end{array}$ \\
\hline Log EPC & & -0.129 & -0.481 \\
\hline EPC band = F/G vs.: & Reference & & \\
\hline EPC band B & $-0.345 *$ & & \\
\hline EPC band C & -0.230 & & \\
\hline EPC band D & -0.065 & & \\
\hline EPC band E & $-0.283^{*}$ & & \\
\hline \multicolumn{4}{|l|}{ Interaction Terms (Property Type vs. Log EPC) } \\
\hline Detached vs. Log EPC & & & Reference \\
\hline Semi-detached vs. Log EPC & & & 0.308 \\
\hline Terraced House vs. Log EPC & & & 0.626 \\
\hline Flat vs. Log EPC & & & 0.366 \\
\hline Log Monthly Rent & $-0.173^{*}$ & -0.035 & $-0.185^{*}$ \\
\hline Number of bedrooms & 0.050 & 0.026 & 0.052 \\
\hline Log floor area in $\mathrm{m} 2$ & 0.073 & 0.055 & 0.076 \\
\hline Tenure freehold $=$ yes & -0.033 & 0.013 & -0.024 \\
\hline City or Urban area $=$ yes & -0.105 & $-0.146 * *$ & -0.103 \\
\hline Log multiple IMD score & $0.062 *$ & 0.003 & $0.061^{*}$ \\
\hline Constant & $3.536 * * *$ & $4.024 * * *$ & $5.379 * *$ \\
\hline
\end{tabular}




\begin{tabular}{|c|c|c|c|}
\hline Quarterly fixed effects & Yes & Yes & Yes \\
\hline Regional fixed effects & Yes & Yes & Yes \\
\hline$R$-squared (model fit) & 0.03 & 0.01 & 0.02 \\
\hline Sample Size & 4,069 & 4,069 & 4,069 \\
\hline
\end{tabular}

Asterisks indicate significance levels: $* \mathrm{p}=0.05,{ }^{* *} \mathrm{p}=0.01$ and $* * * \mathrm{p}=0.001$. Robust standard errors are used. Complete results are shown in the Appendix G.

Previous studies also report that, although the physical characteristics of a rental unit are important drivers, time-on-market also varies systematically with factors such as tenant mobility (Guasch and Marshall, 1985). This implies that additional determinants of the marketing period are unaccounted for in the estimation of the coefficients. Despite being inconclusive, two interesting observations emerge from these results.

Firstly, the negative coefficient of rent level indicates that rental units with relatively higher listed rental prices are likely to stay listed for longer, with the caveat that the equilibrium rent level is assumed to be set exogenously, but landlords can deviate from this equilibrium by setting too high or too low asking rents, which would in turn affect time-on-market. Secondly, in Model 1, B and E-rated rental units are predicted to achieve a relevant statistically significant lower time-on-market in comparison to those in the lowest EPC category of F/G. The remaining coefficients of energy efficiency bands and the energy efficiency score are not statistically significant.

\subsection{Research findings connection with previous comparable studies}

The positive price premiums reported in the present study for dwellings with favourable energy efficiency ratings are consistent with the hedonic buy-to-let analysis of Fuerst et al. (2016) in Wales and particularly the significant premiums found for the overall housing market in England (Fuerst et al., 2015). However, a diverging result compared to the Wales study is our finding of a significant price discount for $\mathrm{F}$ and $\mathrm{G}$ rated buy-to-let properties. Consequently, the present paper's results for England do not appear to support the conclusion of the previous Wales study, in which PRS buyers do not price-discriminate against low-rated properties to the 
same extent as owner occupiers due to the split incentive problem. While it would be necessary to directly compare a matched sample of owner-occupied versus buy-to-let dwellings in England for a full assessment of this question, the diverging findings for the bottom-rated EPC group may be due to inherent structural differences of the stock and/or time period considered in those studies.

\subsection{Implications for theory and practice on sustainability}

The importance of property energy reduction relies on the fact that buildings are resposnible for approximattely $40-50 \%$ of energy consumption globally as well as $33 \%$ of greenhouse gas emissions (Castleton et al., 2010; Berardi et al., 2014). Moreover, improving the housing stock is one of the major targets of the European Union, for example in its Energy Efficiency Directive 2012/27/EU (EED) (Femenías et al., 2018). Overall, the results provided by the present study reveal a statistically significant relationship between energy performance as captured by the EPC and market prices. Therefore, price premiums are reported for buildings with favourable energy efficiency levels and, conversely, price discounts are tied to less efficient energy properties. The importance of such results relies on the fact that it empirically supports the subject perception of economic value added by charging higher rental rates as a compensation of green property investments.

The realisation of economic value-added as a return on green property investment through higher rental rates can a be a relevant incentive to increase such investments, which is highly desirable since public investment on building production made by European countries has been reduced and public funds are scarce. Therefore, the effective implementation of energy saving policies relies more on market forces - such as the ones explored in the present study - than on public financial support (Gruis, 2008; Copiello, 2015; Femenías et al., 2018).

\section{Conclusions}


A demonstrable link between achievable PRS rents and energy efficiency levels is crucial for landlords to have a monetary incentive for investing in energy efficiency. The results of the empirical analysis confirm that energy efficiency features exert a small but broadly significant influence on both transaction prices and quoted rental prices. A model of time-on-market against similar control variables yields inconclusive results but there is, albeit weak, evidence of a negative relationship between time-on-market and energy efficiency rating.

Future research may aim to further unravel the causal relationship between energy efficiency and prices by analysing changes in observed or perceived energy efficiency features in the same dwelling units over time. Also, as the present analysis could not control for the general state of repair of a rental property, follow-up studies examining physical characteristics such as new kitchens, bathrooms or the general quality of the property are warranted.

Overall, consistent with the extant literature on drivers of 'green' investments in the housing market, the results provide further empirical evidence on the relationship between energy efficiency ratings and pricing decisions in the PRS and demonstrate that the features captured by EPCs are broadly significant price and rent determinants. 


\section{References}

Adan, H., \& Fuerst, F. (2015). Modelling energy retrofit investments in the UK housing market: A microeconomic approach. Smart and Sustainable Built Environment, 4(3), 251-267.

Allen, M. T., Springer, T. M., \& Waller, N. G. (1995). Implicit pricing across residential rental submarkets. The Journal of Real Estate Finance and Economics, 11(2), 137-151.

Amecke, H. (2012). The impact of energy performance certificates: A survey of German home owners. Energy Policy, 46, 4-14.

Balk, B., Haan, J. D., \& Diewert, W. E. (2013). Handbook on Residential Property Price Indices (RPPIs). World Bank Group.

Berardi, U., GhaffarianHoseini, A., \& GhaffarianHoseini, A. (2014). State-of-the-art analysis of the environmental benefits of green roofs. Applied energy, 115, 411-428.

Berry, S., Marker, T., \& Chevalier, T. (2008, September). Modelling the relationship between energy efficiency attributes and house price: the case of detached houses sold in the Australian capital territory in 2005 and 2006. In World Sustainable Building Conference, Melbourne (pp. 21-25).

Bracke, P. (2015). How much do investors pay for houses? Real Estate Economics.

Brounen, D., \& Kok, N. (2011). On the economics of energy labels in the housing market. Journal of Environmental Economics and Management, 62(2), 166-179.

Cajias, M., \& Piazolo, D. (2013). Green performs better: energy efficiency and financial return on buildings. Journal of Corporate Real Estate, 15(1), 53-72.

Castleton, H. F., Stovin, V., Beck, S. B., \& Davison, J. B. (2010). Green roofs; building energy savings and the potential for retrofit. Energy and buildings, 42(10), 1582-1591.

Cerin, P., Hassel, L. G., \& Semenova, N. (2014). Energy performance and housing prices. Sustainable Development, 22(6), 404-419.

Chen, F. Y., Peng, I. W., Liang, J. H., \& Liang, Y. Y. (2014). Green premium in green condo buildings? Evidence in Taiwan. Green Building, Materials and Civil Engineering, 7-11.

Copiello, S. (2015). Achieving affordable housing through energy efficiency strategy. Energy Policy, 85, 288-298.

Davis, P. T., McCord, J. A., McCord, M., \& Haran, M. (2015). Modelling the effect of energy performance certificate rating on property value in the Belfast housing market. International Journal of Housing Markets and Analysis, 8(3), 292-317.

Deng, Y., Li, Z., \& Quigley, J. M. (2012). Economic returns to energy-efficient investments in the housing market: evidence from Singapore. Regional Science and Urban Economics, 42(3), 506-515.

DiPasquale, D., \& Wheaton, W. C. (1992). The markets for real estate assets and space: A conceptual framework. Real Estate Economics, 20(2), 181-198. 
Femenías, P., Mjörnell, K., \& Thuvander, L. (2018). Rethinking deep renovation: The perspective of rental housing in Sweden. Journal of Cleaner Production, 195, 1457-1467.

Fuerst, F., McAllister, P., Nanda, A., \& Wyatt, P. (2015). Does energy efficiency matter to home-buyers? An investigation of EPC ratings and transaction prices in England. Energy Economics, 48, 145-156.

Fuerst, F., McAllister, P., Nanda, A., \& Wyatt, P. (2016). Energy performance ratings and house prices in Wales: An empirical study. Energy Policy, 92, 20-33.

Gruis, V. (2008). Organisational archetypes for Dutch housing associations. Environment and Planning C: Government and Policy, 26(6), 1077-1092.

Guasch, J. L., \& Marshall, R. C. (1985). An analysis of vacancy patterns in the rental housing market. Journal of Urban Economics, 17(2), 208-229.

Högberg, L. (2013). The impact of energy performance on single-family home selling prices in Sweden. Journal of European Real Estate Research, 6(3), 242-261.

Hyland, M., Lyons, R. C., \& Lyons, S. (2013). The value of domestic building energy efficiency-evidence from Ireland. Energy Economics, 40, 943-952.

Jaffe, A. B., \& Stavins, R. N. (1994). The energy-efficiency gap. What does it mean?. Energy policy, 22(10), 804-810.

Jensen, O. M., Hansen, A. R., \& Kragh, J. (2016). Market response to the public display of energy performance rating at property sales. Energy Policy, 93, 229-235.

Kahn, M. E., \& Kok, N. (2014). The capitalization of green labels in the California housing market. Regional Science and Urban Economics, 47, 25-34.

Kain, J. F., \& Quigley, J. M. (1970). Measuring the value of housing quality. Journal of the American statistical association, 65(330), 532-548.

Kholodilin, K. A., Mense, A., \& Michelsen, C. (2017). The market value of energy efficiency in buildings and the mode of tenure. Urban Studies, 54(14), 3218-3238.

O'Malley, E., Scott, S., \& Sorrell, S. (2003). Barriers to energy efficiency: Evidence from selected sectors.

Paragon Group. (2015). Today's Private Rented Sector. A Home for One in Five Households. Retrieved from https://www.paragonbankinggroup.co.uk/resources/paragongroup/documents/publications/20 15/prsreport-2015

Potepan, M. J. (1996). Explaining intermetropolitan variation in housing prices, rents and land prices. Real Estate Economics, 24(2), 219-245.

Rehdanz, K. (2007). Determinants of residential space heating expenditures in Germany. Energy Economics, 29(2), 167-182. 
Rosen, S. (1974). Hedonic prices and implicit markets: product differentiation in pure competition. Journal of political economy, 82(1), 34-55.

Samuelson, P. A. (1959). A modern treatment of the Ricardian economy: I. The pricing of goods and of labor and land services. The Quarterly Journal of Economics, 73(1), 1-35.

Sorrell, S. (2003). Making the link: climate policy and the reform of the UK construction industry. Energy Policy, 31(9), 865-878.

Yoshida, J., \& Sugiura, A. (2010). Which "greenness" is valued? Evidence from green condominiums in Tokyo. Munich Personal RePEc Archive.

Zalejska-Jonsson, A. (2014). Stated WTP and rational WTP: Willingness to pay for green apartments in Sweden. Sustainable Cities and Society, 13, 46-56.

Zheng, S., Wu, J., Kahn, M. E., \& Deng, Y. (2012). The nascent market for "green" real estate in Beijing. European Economic Review, 56(5), 974-984. 


\section{Appendices}

\section{Appendix A}

Table A.1

Overview of selected studies on energy efficiency capitalisation in the housing market.

\begin{tabular}{|c|c|c|c|}
\hline Study & Methodology & Country & Results \\
\hline $\begin{array}{l}\text { Amecke } \\
(2012)\end{array}$ & $\begin{array}{l}\text { Standard hedonic } \\
\text { model }\end{array}$ & Germany & $\begin{array}{l}\text { Energy performance certificates have a limited } \\
\text { effect on purchasing decisions }\end{array}$ \\
\hline $\begin{array}{l}\text { Berry et al., } \\
(2008)\end{array}$ & $\begin{array}{l}\text { Standard hedonic } \\
\text { model }\end{array}$ & Australia & $\begin{array}{l}\text { A, B or C rated properties command premiums of } \\
10 \%, 5.5 \% \text { and } 2.2 \%\end{array}$ \\
\hline $\begin{array}{l}\text { Brounen and } \\
\text { Kok. }(2011)\end{array}$ & $\begin{array}{l}\text { Heckman's two-step } \\
\text { estimation (FGLS) }\end{array}$ & Netherlands & $\begin{array}{l}\text { Building with a green label sells at a premium of } \\
3.6 \%\end{array}$ \\
\hline $\begin{array}{l}\text { Cerin et al., } \\
(2014)\end{array}$ & $\begin{array}{l}\text { Standard hedonic } \\
\text { model }\end{array}$ & Sweden & $\begin{array}{l}\text { Energy rating, on average, does not contribute to } \\
\text { the market price premium of a house }\end{array}$ \\
\hline $\begin{array}{l}\text { Chen et al., } \\
(2014)\end{array}$ & $\begin{array}{l}\text { Standard hedonic } \\
\text { model }\end{array}$ & Taiwan & $\begin{array}{l}\text { Price premium exists for green features but } \\
\text { premium for green label is not significant }\end{array}$ \\
\hline $\begin{array}{l}\text { Davis et al., } \\
(2015)\end{array}$ & $\begin{array}{l}\text { Standard hedonic } \\
\text { model }\end{array}$ & $\begin{array}{l}\text { Northern } \\
\text { Ireland }\end{array}$ & $\begin{array}{l}\text { A small but positive relationship between energy } \\
\text { performance and sale prices }\end{array}$ \\
\hline $\begin{array}{l}\text { Deng et al., } \\
(2012)\end{array}$ & $\begin{array}{l}\text { Standard hedonic } \\
\text { model and fixed } \\
\text { effect }\end{array}$ & Singapore & $\begin{array}{l}\text { Substantial economic returns to green buildings in } \\
\text { Singapore }\end{array}$ \\
\hline $\begin{array}{l}\text { Fuerst et al., } \\
(2015)\end{array}$ & $\begin{array}{l}\text { Standard hedonic } \\
\text { model }\end{array}$ & England & $\begin{array}{l}14 \% \text { premium of the highest band of energy } \\
\text { ratings }\end{array}$ \\
\hline $\begin{array}{l}\text { Fuerst et al., } \\
\text { (2016) }\end{array}$ & $\begin{array}{l}\text { Standard hedonic } \\
\text { model }\end{array}$ & Wales & $\begin{array}{l}18.5 \% \text { and } 4 \% \text { for } \mathrm{A} / \mathrm{B} \text { rated and } \mathrm{C} \text { rated buy-to- } \\
\text { let properties and no significant discount for } \\
\text { lower-rated properties }\end{array}$ \\
\hline $\begin{array}{l}\text { Hyland et al., } \\
\text { (2013) }\end{array}$ & $\begin{array}{l}\text { Standard hedonic } \\
\text { model }\end{array}$ & Ireland & $\begin{array}{l}\text { A-rated property receives a price premium of } \\
11 \% \text {, and B-rated properties increase the price by } \\
5.8 \%\end{array}$ \\
\hline $\begin{array}{l}\text { Högberg } \\
(2013)\end{array}$ & $\begin{array}{l}\text { Standard hedonic } \\
\text { model }\end{array}$ & Sweden & $\begin{array}{l}\text { Home buyers consider the information in the } \\
\text { EPCs, entailing a price premium }\end{array}$ \\
\hline $\begin{array}{l}\text { Jensen et al., } \\
(2016)\end{array}$ & $\begin{array}{l}\text { Standard hedonic } \\
\text { model }\end{array}$ & Denmark & $\begin{array}{l}\text { Energy performance rating of properties play an } \\
\text { important role in relation to sale price }\end{array}$ \\
\hline $\begin{array}{l}\text { Kahn and } \\
\text { Kok (2014) }\end{array}$ & $\begin{array}{l}\text { Standard hedonic } \\
\text { model and } \\
\text { propensity score } \\
\text { matching }\end{array}$ & USA & Green price premiums of $2-4 \%$ \\
\hline $\begin{array}{l}\text { Yoshida and } \\
\text { Sugiura } \\
(2010)\end{array}$ & $\begin{array}{l}\text { Standard hedonic } \\
\text { model }\end{array}$ & Japan & $\begin{array}{l}\text { Green residential buildings trade at a price } \\
\text { discount of } 5.5 \%\end{array}$ \\
\hline $\begin{array}{l}\text { Zheng et al., } \\
(2012)\end{array}$ & $\begin{array}{l}\text { Standard hedonic } \\
\text { model }\end{array}$ & China & $\begin{array}{l}\text { Significant price premia for 'green' properties in } \\
\text { the Chinese housing market }\end{array}$ \\
\hline
\end{tabular}

\section{Appendix B}

Table B.1.

Descriptive statistics for key variables $(n=2,202)$.

\begin{tabular}{lll}
\hline Continuous variables & Mean & Std. Dev. \\
\hline Price (P1) & 127,860 & 258,666 \\
Price (P2) & 172,662 & 358,311 \\
Compound annual growth rate (\%) & $4.47 \%$ & $6.70 \%$
\end{tabular}




\begin{tabular}{|c|c|c|c|}
\hline Total floor area $\left(\mathrm{m}^{2}\right)$ & 80 & 35 & \\
\hline Energy efficiency rating & 59 & 14 & \\
\hline Categorical variables & Categories & Frequency & $\%$ of total \\
\hline \multirow[t]{4}{*}{ Dwelling type } & Detached & 221 & $10.04 \%$ \\
\hline & Flat & 213 & $9.67 \%$ \\
\hline & $\begin{array}{l}\text { Semi- } \\
\text { Detached }\end{array}$ & 583 & $26.48 \%$ \\
\hline & Terrace & 1,185 & $53.81 \%$ \\
\hline \multirow{2}{*}{ Tenure } & $\begin{array}{l}\text { House } \\
\text { Freehold }\end{array}$ & 1,820 & $82.65 \%$ \\
\hline & Leasehold & 382 & $17.35 \%$ \\
\hline \multirow[t]{12}{*}{ Vintage class } & Missing & 275 & $12.49 \%$ \\
\hline & Before 1900 & 326 & $14.80 \%$ \\
\hline & 1900-1929 & 491 & $22.30 \%$ \\
\hline & 1930-1949 & 187 & $8.49 \%$ \\
\hline & 1950-1966 & 152 & $6.90 \%$ \\
\hline & 1967-1975 & 115 & $5.22 \%$ \\
\hline & 1976-1982 & 100 & $4.54 \%$ \\
\hline & 1983-1990 & 155 & $7.04 \%$ \\
\hline & 1991-1995 & 112 & $5.09 \%$ \\
\hline & 1996-2002 & 158 & $7.18 \%$ \\
\hline & 2003-2006 & 111 & $5.04 \%$ \\
\hline & 2007 onwards & 20 & $0.91 \%$ \\
\hline \multirow[t]{8}{*}{ Number of bedrooms } & Missing & 65 & $2.95 \%$ \\
\hline & 0 & 1 & $0.05 \%$ \\
\hline & 1 & 143 & $6.49 \%$ \\
\hline & 2 & 929 & $42.19 \%$ \\
\hline & 3 & 768 & $34.88 \%$ \\
\hline & 4 & 225 & $10.22 \%$ \\
\hline & 5 & 48 & $2.18 \%$ \\
\hline & $5+$ & 22 & $1.30 \%$ \\
\hline \multirow[t]{7}{*}{ Energy efficiency band } & A & 0 & $0.00 \%$ \\
\hline & B & 48 & $2.18 \%$ \\
\hline & $\mathrm{C}$ & 526 & $23.89 \%$ \\
\hline & $\mathrm{D}$ & 942 & $42.78 \%$ \\
\hline & E & 546 & $24.85 \%$ \\
\hline & $\mathrm{F}$ & 107 & $4.86 \%$ \\
\hline & $\mathrm{G}$ & 33 & $1.50 \%$ \\
\hline \multirow[t]{2}{*}{ Urban/ rural } & Urban & 1,782 & $80.93 \%$ \\
\hline & Rural & 420 & $19.07 \%$ \\
\hline \multirow[t]{7}{*}{ IMD decile where IMD- 1 is the most deprived $10 \%$ of LSOA } & Missing & 116 & $5.27 \%$ \\
\hline & IMD-1 & 179 & $8.13 \%$ \\
\hline & IMD-2 & 201 & $9.13 \%$ \\
\hline & IMD-3 & 195 & $8.86 \%$ \\
\hline & IMD-4 & 227 & $10.31 \%$ \\
\hline & IMD-5 & 238 & $10.81 \%$ \\
\hline & IMD-6 & 221 & $10.04 \%$ \\
\hline
\end{tabular}




$\begin{array}{lll}\text { IMD-7 } & 197 & 8.95 \% \\ \text { IMD-8 } & 218 & 9.90 \% \\ \text { IMD-9 } & 212 & 9.63 \% \\ \text { IMD-10 } & 198 & 8.99 \%\end{array}$

\section{Appendix C}

Table C.1.

Energy rating and sale price: hedonic estimations.

Dependent variable: logarithm of sale price per $m^{2}$.

\begin{tabular}{|c|c|c|c|}
\hline Variable & Model 1 & Model 2 & Model 3 \\
\hline Log EPC & & & $0.119 * * *$ \\
\hline EPC band = D vs.: & Reference & Reference & \\
\hline EPC band $\mathrm{B} / \mathrm{C}$ & $0.061 * * *$ & $0.063 * * *$ & \\
\hline EPC band E & 0.004 & 0.001 & \\
\hline EPC band F/G & $-0.101^{*}$ & $-0.112 * *$ & \\
\hline Property type $=$ Detached vs.: & Reference & Reference & Reference \\
\hline Semi-detached & $-0.181 * * *$ & $-0.197 * * *$ & $-0.188 * * *$ \\
\hline Terraced House & $-0.346 * * *$ & $-0.367 * * *$ & $-0.355 * * *$ \\
\hline Flat & 0.007 & -0.002 & 0.011 \\
\hline Number of bedrooms & $0.119 * * *$ & $0.118 * * *$ & $0.118^{* * *}$ \\
\hline Log floor area in $\mathrm{m}^{2}$ & $-0.587 * * *$ & $-0.573 * * *$ & $-0.573 * * *$ \\
\hline Tenure freehold $=$ yes & $0.194 * * *$ & $0.187 * * *$ & $0.191 * * *$ \\
\hline Rural area $=$ yes & 0.000 & 0.014 & 0.015 \\
\hline Purchased brand new & -0.033 & -0.038 & -0.037 \\
\hline Vintage class $=$ Post 2002 vs.: & Reference & Reference & Reference \\
\hline Missing & $-0.177 * * *$ & $-0.179 * * *$ & $-0.185 * * *$ \\
\hline Pre 1900 & $-0.174 * * *$ & $-0.167 * * *$ & $-0.184 * * *$ \\
\hline 1900-1929 & $-0.305 * * *$ & $-0.302 * * *$ & $-0.315 * * *$ \\
\hline 1930-1949 & $-0.312 * * *$ & $-0.313^{* * *}$ & $-0.319 * * *$ \\
\hline $1950-1966$ & $-0.445^{* * *}$ & $-0.444 * * *$ & $-0.452 * * *$ \\
\hline 1967-1975 & $-0.308 * * *$ & $-0.321 * * *$ & $-0.334 * * *$ \\
\hline 1976-1982 & $-0.262 * * *$ & $-0.261 * * *$ & $-0.271 * * *$ \\
\hline $1983-1990$ & $-0.307 * * *$ & $-0.305^{* * *}$ & $-0.312 * * *$ \\
\hline 1991-1995 & $-0.201 * * *$ & $-0.207 * * *$ & $-0.218 * * *$ \\
\hline $1996-2002$ & $-0.113 * * *$ & $-0.117 * * *$ & $-0.118 * * *$ \\
\hline Log multiple IMD score & Components & $0.038 * * *$ & $0.038 * * *$ \\
\hline Log employment score & $0.039^{* * *}$ & & \\
\hline Log education score & $0.041 * * *$ & & \\
\hline Log health score & $0.024 * * *$ & & \\
\hline Log income score & $0.021 * *$ & & \\
\hline Log crime score & 0.010 & & \\
\hline Log barriers to housing score & -0.005 & & \\
\hline Log living environment score & 0.012 & & \\
\hline Constant & $8.964 * * *$ & $9.615 * * *$ & $9.141 * * *$ \\
\hline
\end{tabular}




\begin{tabular}{lccc} 
Quarterly fixed effects & Yes & Yes & Yes \\
Regional fixed effects & Yes & Yes & Yes \\
\hline R-squared (model fit) & 0.44 & 0.43 & 0.43 \\
Sample Size & 4,132 & 4,132 & 4,132 \\
\hline Asterisks indicate significance levels: $* \mathrm{p}=0.05 * * \mathrm{p}=0.01$ and $* * * \mathrm{p}=0$ 001. & Robust standard errors are used
\end{tabular}

Asterisks indicate significance levels: $* \mathrm{p}=0.05,{ }^{*} \mathrm{p}=0.01$ and $* * * \mathrm{p}=0.001$. Robust standard errors are used.

Appendix D: Distribution charts of dwelling characteristics.

Fig. D.1. Sample proportion of vintage classes.

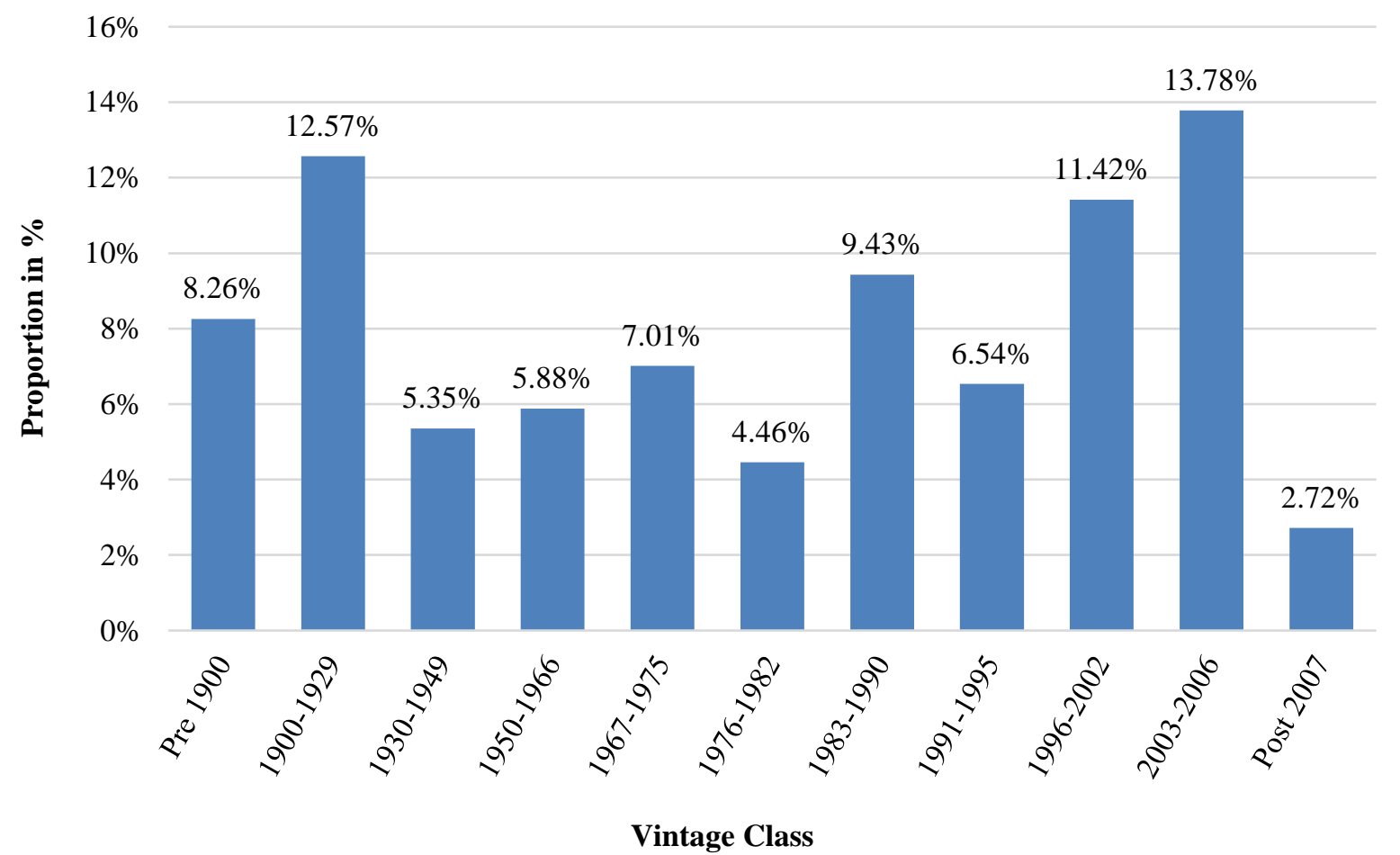


Fig. D.2. Sample proportion of dwelling types.

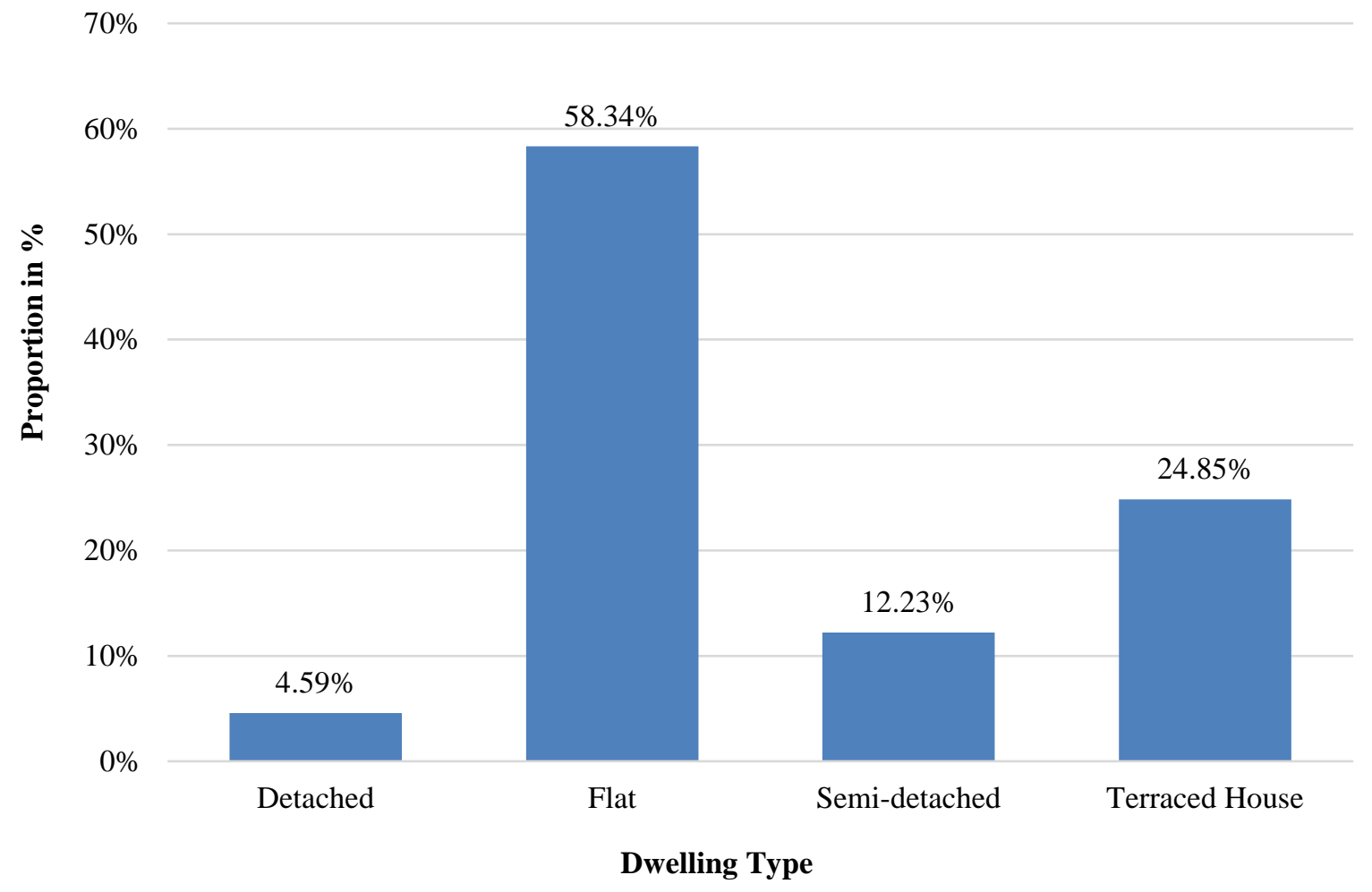

Fig. D.3. English IMD deciles.

$14 \%$

$12.29 \%$

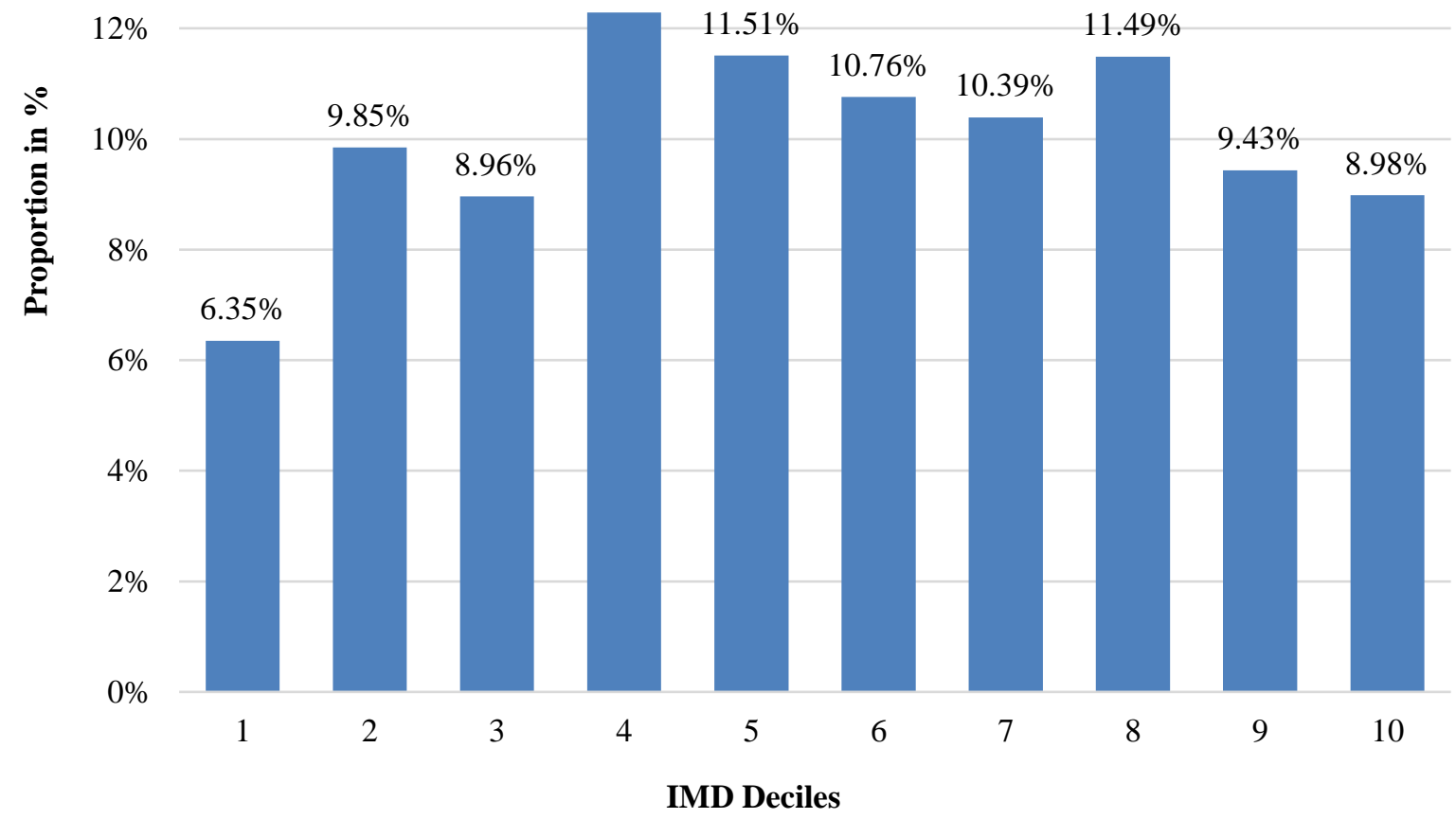


Fig. D.4. Sample proportion related to the number of bedrooms.

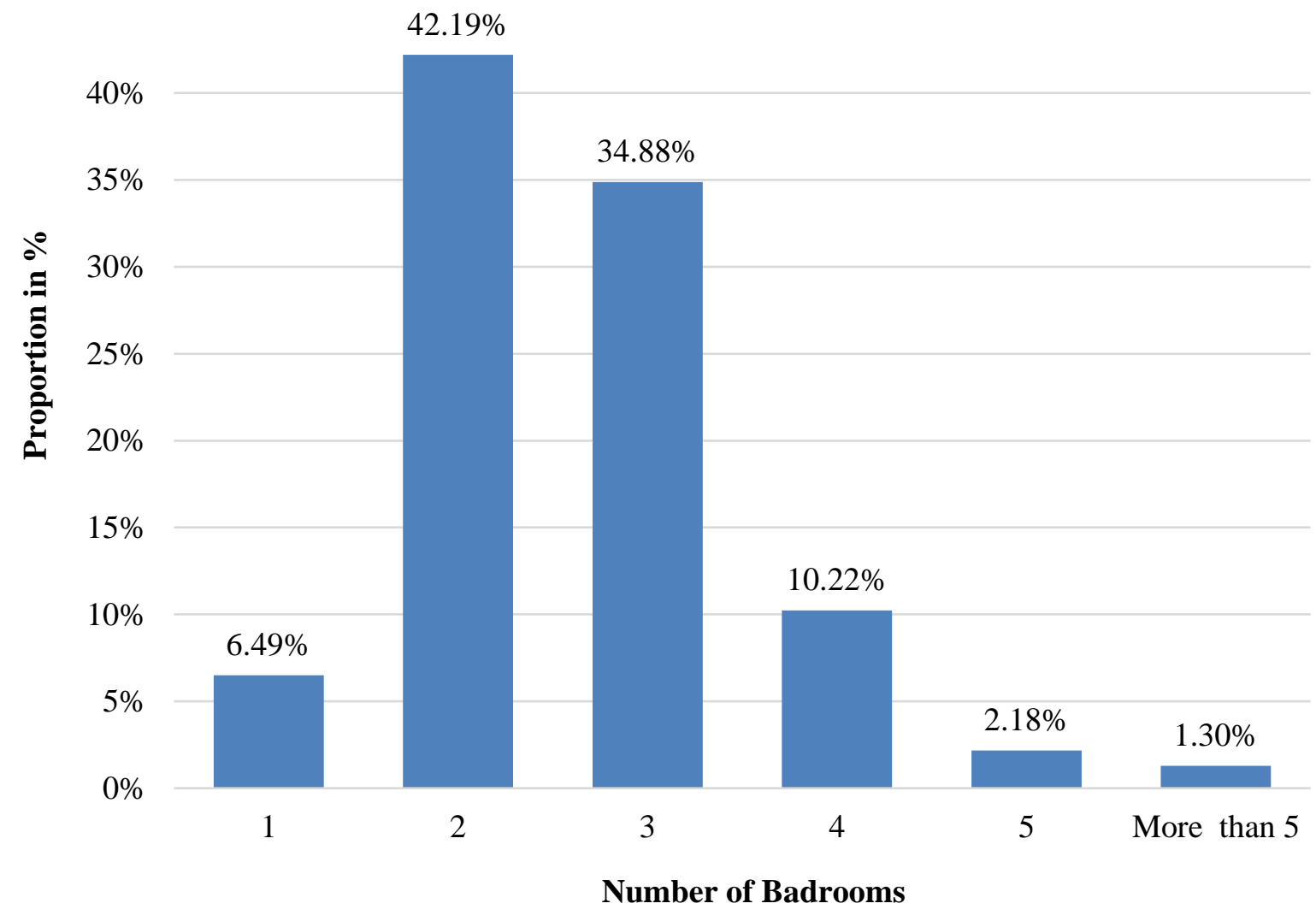

\section{Appendix $E$}

Table E.1.

Descriptive statistics of the categorical data in the sample $(n=4,702)$.

\begin{tabular}{llll}
\hline Variable & Categories & Frequency & \% of total \\
\hline Dwelling type & Detached & 216 & 4.59 \\
& Flat & 2,747 & 58.34 \\
Vintage class & Semi detached & 576 & 12.23 \\
& Terraced House & 1,170 & 24.85 \\
& Missing & 592 & 12.57 \\
& Pre 1900 & 389 & 8.26 \\
& $1900-1929$ & 592 & 12.57 \\
& $1930-1949$ & 252 & 5.35 \\
& $1950-1966$ & 277 & 5.88 \\
Number of bedrooms & $1967-1975$ & 330 & 7.01 \\
& $1976-1982$ & 210 & 4.46 \\
& $1983-1990$ & 444 & 9.43 \\
& $1991-1995$ & 308 & 6.54 \\
& $1996-2002$ & 538 & 11.42
\end{tabular}




\begin{tabular}{|c|c|c|c|}
\hline & 1 & 723 & 15.6 \\
\hline & 2 & 2,790 & 60.21 \\
\hline & 3 & 833 & 17.98 \\
\hline & 4 & 219 & 4.73 \\
\hline & $5+$ & 69 & 1.46 \\
\hline \multirow[t]{7}{*}{ EPC rating } & A & 1 & 0.02 \\
\hline & $\mathrm{B}$ & 494 & 10.49 \\
\hline & $\mathrm{C}$ & 1,666 & 35.38 \\
\hline & $\mathrm{D}$ & 1,596 & 33.89 \\
\hline & $\mathrm{E}$ & 739 & 15.69 \\
\hline & $\mathrm{F}$ & 173 & 3.67 \\
\hline & $\mathrm{G}$ & 40 & 0.85 \\
\hline \multirow[t]{10}{*}{ IMD decile where 1 is the most deprived $10 \%$} & 1 & 271 & 6.35 \\
\hline & 2 & 420 & 9.85 \\
\hline & 3 & 382 & 8.96 \\
\hline & 4 & 524 & 12.29 \\
\hline & 5 & 491 & 11.51 \\
\hline & 6 & 459 & 10.76 \\
\hline & 7 & 443 & 10.39 \\
\hline & 8 & 490 & 11.49 \\
\hline & 9 & 402 & 9.43 \\
\hline & 10 & 383 & 8.98 \\
\hline \multirow[t]{2}{*}{ Urban/ rural } & Urban & 4,066 & 86.35 \\
\hline & Rural & 643 & 13.65 \\
\hline \multirow[t]{9}{*}{ Region } & North East & 197 & 4.18 \\
\hline & North West & 946 & 20.09 \\
\hline & Yorkshire & 942 & 20 \\
\hline & East Midlands & 522 & 11.09 \\
\hline & West Midlands & 647 & 13.74 \\
\hline & East of England & 301 & 6.39 \\
\hline & London & 385 & 8.18 \\
\hline & South East & 436 & 9.26 \\
\hline & South West & 333 & 7.07 \\
\hline
\end{tabular}

\section{Appendix $\mathrm{F}$}

\section{Table F.1.}

Energy rating and rental price: hedonic estimations.

Dependent variable: log of monthly rent per $\mathrm{m}^{2}$.

\begin{tabular}{lccc}
\hline Variable & Model 1 & Model 2 & Model 3 \\
\hline Log EPC & & & -0.159 \\
EPC band = D vs.: & Reference & Reference & \\
EPC band B & $0.038^{*}$ & 0.026 & \\
EPC band C & $0.049^{* * *}$ & $0.030^{* * *}$ & \\
EPC band E & -0.001 & 0.001 &
\end{tabular}


EPC band F/G

Property type $=$ Detached vs.:

Semi-detached

Terraced House

Flat

Interaction Terms (Property Type vs. Log EPC)

Detached vs. Log EPC

Semi-detached vs. Log EPC

Terraced House vs. Log EPC

Flat vs. Log EPC

Number of bedrooms

Log floor area in $\mathrm{m}^{2}$

Tenure freehold $=$ yes

City or Urban area $=$ yes

Vintage class $=$ Post 1995 vs.:

Missing

Pre 1900

1900-1929

1930-1949

1950-1966

1967-1975

1976-1982

1983-1990

1991-1995

Log multiple IMD score

Log employment score

Log education score

Log health score

Log income score

Log crime score

Log barriers to housing score

Log living environment score

Constant

Quarterly fixed effects

Regional fixed effects

$R$-squared (model fit)

Sample Size
$-0.035 \quad-0.049 * *$

$\begin{array}{ccc}\text { Reference } & \text { Reference } & \text { Reference } \\ -0.091 * * * & -0.090 * * * & -1.063 * * \\ -0.142 * * * & -0.157 * * * & -1.125 * * * \\ -0.065 & -0.157 * * * & -1.082 * *\end{array}$

Reference

$0.237 * *$

$0.239 * *$

$0.247 * *$

$0.112 * * *$

$-0.705 * * *$

0.023

$0.096^{* * *}$

$0.113 * * *$

$-0.703 * * *$

0.014

$0.068 * * *$

Reference

0.015

$-0.014$

0.006

$-0.046$

$-0.048$

$-0.035$

$-0.038$

$-0.028$

$-0.745^{* * *}$

0.016

$0.061 * * *$

0.006

$0.051 * * *$

Reference

0.008

$-0.023$

$-0.002$

$-0.058 * *$

$-0.051 *$

$-0.053 * *$

$-0.044^{*}$

$-0.032 *$

$-0.003$

Components

$0.024 * * *$

$0.023 * * *$

$0.011 * *$

$0.022 * * *$

$-0.001$

$-0.009$

$0.020 * * *$

$4.115 * * *$

$4.828 * * *$

$5.247 * * *$

Yes

Yes

Yes

Yes

Yes Yes

0.63

4,076

4,076

Asterisks indicate significance levels: $* \mathrm{p}=0.05, * * \mathrm{p}=0.01$ and $* * * \mathrm{p}=0.001$. Robust standard errors are used.

\section{Appendix $G$}

Table G.1.

Energy rating and time-on-market: hedonic estimations.

Dependent variable: log of time-on-market in days.

Variable

Model 1

Model 2

Model 3

Log EPC

$-0.129$

$-0.481$ 
EPC band $=$ F/G vs.:

EPC band B

EPC band $\mathrm{C}$

EPC band D

EPC band E

Property type $=$ Detached vs.:

Semi-detached

Terraced House

Flat

Interaction Terms (Property Type vs. Log EPC)

Detached vs. Log EPC

Semi-detached vs. Log EPC

Terraced House vs. Log EPC

Flat vs. Log EPC

Log Monthly Rent

Number of bedrooms

Log floor area in $\mathrm{m} 2$

Tenure freehold $=$ yes

City or Urban area $=$ yes

Vintage class $=$ Post 1995 vs.:

Missing

Pre 1900

1900-1929

1930-1949

1950-1966

1967-1975

1976-1982

1983-1990

1991-1995

Log multiple IMD score

Constant

Quarterly fixed effects

Regional fixed effects

$R$-squared (model fit)

Sample Size
Reference

$-0.345^{*}$

$-0.230$

$-0.065$

$-0.283 *$

Reference

0.212

0.251

0.209

Reference
0.168
$0.209^{*}$
0.189

Reference

$-1.070$

$-2.322$

$-1.307$

Reference

0.308

0.626

0.366

$-0.173^{*}$

0.050

0.073

$-0.035$

$-0.185^{*}$

0.052

0.076

$-0.033$

0.055

$-0.024$

$-0.105$

0.013

$-0.103$

Reference

0.028

$-0.146^{* *}$

Reference

0.065

$-0.171$

0.026

$-0.094$

$-0.200$

$-0.173^{*}$

$-0.154$

$-0.283^{*}$

$-0.083$

$-0.227$

0.170

$-0.189 *$

0.212

$-0.268^{*}$

0.145

$-0.209$

$-0.225$

$-0.046$

$-0.174$

0.029

$-0.088$

0.083

$-0.109$

0.041

$-0.045$

0.062 *

0.014

$0.061 *$

3.536 ***

0.003

$5.379 * *$

Yes

$4.024 * * *$

Yes

Yes

0.03

Yes

0.02

4,069

0.01

4,069

Asterisks indicate significance levels: ${ }^{*} \mathrm{p}=0.05,{ }^{*} \mathrm{p}=0.01$ and $* * * \mathrm{p}=0.001$. Robust standard errors are used. 